\title{
The 13 November 2007 rock-fall at Viale Tiziano in Rome (Italy)
}

\author{
M. Amanti, V. Chiessi, and P. M. Guarino \\ Institute for Environmental Protection and Research, Rome, Italy \\ Correspondence to: M. Amanti (marco.amanti@isprambiente.it)
}

Received: 26 September 2011 - Revised: 20 March 2012 - Accepted: 21 March 2012 - Published: 21 May 2012

\begin{abstract}
The aim of the study was to perform a study on the western slope of the Monti Parioli hill (Rome, Italy) affected by frequent rock-fall phenomena, such as the one that occurred on 13 November 2007.

This goal was achieved by defining a detailed reconstruction of the stratigraphical, geological and geomechanical structure of the slope and by conducting a back-analysis of the rock-fall event using 2-D and 3-D modeling tools.

The reconstruction of the slope's geological structure, characterized by the presence of two anthropogenic cavity systems, and the characterisation of geomechanical properties of outcropping terrains have been realized by means of a detailed geological survey and a campaign of direct and indirect investigations. Therefore, continuous rotary, coring boreholes up to $60 \mathrm{~m}$, collecting undisturbed samples for laboratory tests and performing direct investigations such as SPTs and pressuremeter tests were carried out. The indirect investigations included electrical tomography surveys, linear surface seismic refraction surveys and seismic crosshole tests.

Using the reconstructed geological-technical model, it was possible to define the stability conditions of the slope at the time of collapse by using a computational two-dimensional explicit finite difference program (FLAC) and a 3-D finite element analysis (FEMLAB).
\end{abstract}

\section{Introduction}

This paper presents the results of a study conducted by the Geological Survey of Italy (GSI), which is presently part of the Institute for Environmental Protection and Research in Rome, Italy (ISPRA), and the Department of Geological Sciences of the University Roma Tre (UNIROMA3) under an agreement with the Civil Defence Office of Rome Municipality (UEPC). The aim of the study was to define the geological and geomechanical characteristics of the western slope of the Monti Parioli hill in Rome, which was affected by a rock-fall in November 2007.

At that time, the GSI was studying the landslide events in the Municipality of Rome as part of the geological monograph about the Eternal City (Amanti et al., 2008). For this reason, the GSI possessed recent observational data on the geomorphology of the collapsed slope.

Historical research, along with a geological, geomorphological, hydrogeological and structural survey was conducted. A campaign of geognostic investigations, including the collection of undisturbed soil samples, pressuremeter and permeability tests, cross-hole geophysical surveys and electrical and seismic tomography on the slope wall were also conducted.

The field surveys were preceded by the execution of a detailed topographic survey aimed to define a reference plane for the investigation and the subsequent modelling.

The results of the investigations and the slope modelling using both 2-D and 3-D tools are presented in this paper.

\section{The 13 November 2007 rock-fall and other events in the past}

On 13 November 2007 at 11:40 LT, a rock-fall occurred in an area approximately $20 \mathrm{~m}$ wide and $30 \mathrm{~m}$ long on the western slope of Monti Parioli Hill, which sits on Viale Tiziano (Fig. 1). The collapsed material affected half of the road width at a distance of more than $20 \mathrm{~m}$ from the foot of the slope. Several moving and stationary cars were damaged, and three people sustained minor injuries.

The collapsed material, later partially removed by the fire department squads, occupied an area of approximately $200 \mathrm{~m}^{2}$, with a thickness ranging from $1 \mathrm{~m}$ to $4 \mathrm{~m}$. The volume of material in the accumulation area was estimated to be $450 \mathrm{~m}^{3}$ to $600 \mathrm{~m}^{3}$ based on the number of trucks used to 


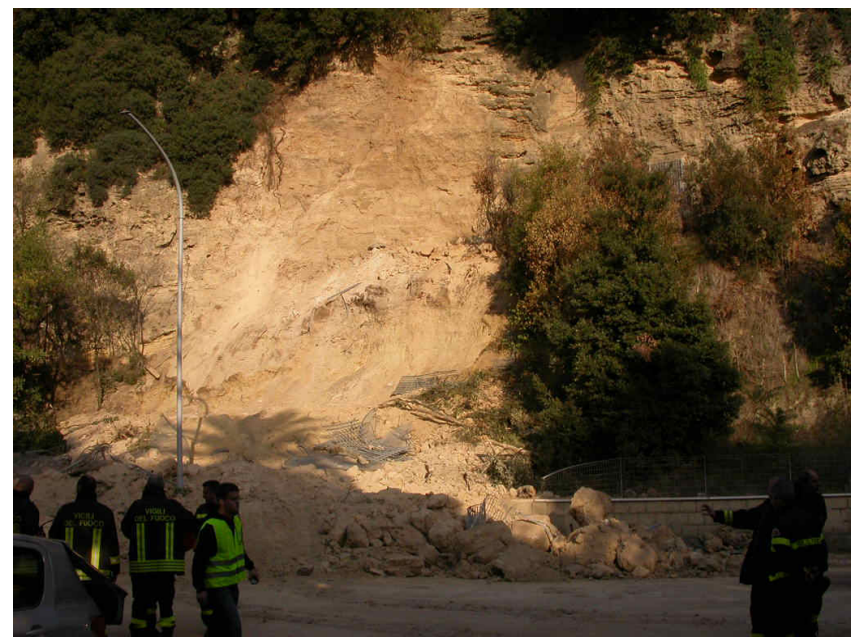

Fig. 1. View of the rock-fall area during the fire department squad's intervention.

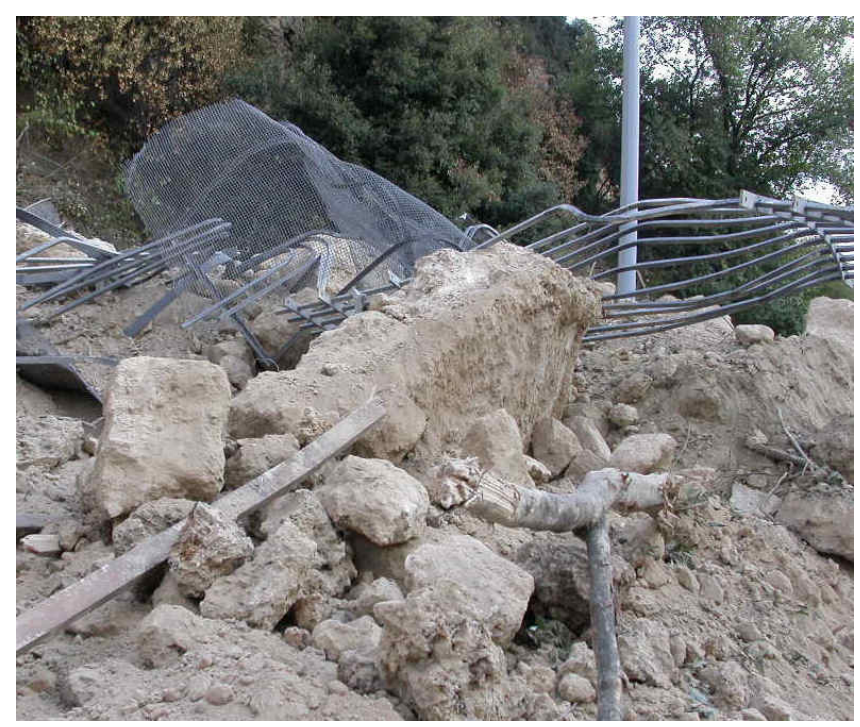

Fig. 2. The fallen mass, mainly composed of sandy material and subordinate lithoid travertine blocks coming from the upper part of the slope; destroyed iron fences, which closed the entrance of a cavity dug in the slope are also visible.

remove the material and on the assessment of the mass missing from the slope. The fallen material was mainly composed of loose, sandy material and subordinate blocks of approximately $1 \mathrm{~m}^{3}$ to $2 \mathrm{~m}^{3}$ (Fig. 2) coming from the middle to upper slope, where the rock has a travertine-like structure.

Since ancient times, the slope has suffered major changes related to human interventions, and it has evolved morphologically through repeated natural collapses and rock-falls (Table 1).

Human interventions to the slope include a cut in Roman times for the passage of the Via Flaminia, whose track was subsequently moved westward approximately $50 \mathrm{~m}$

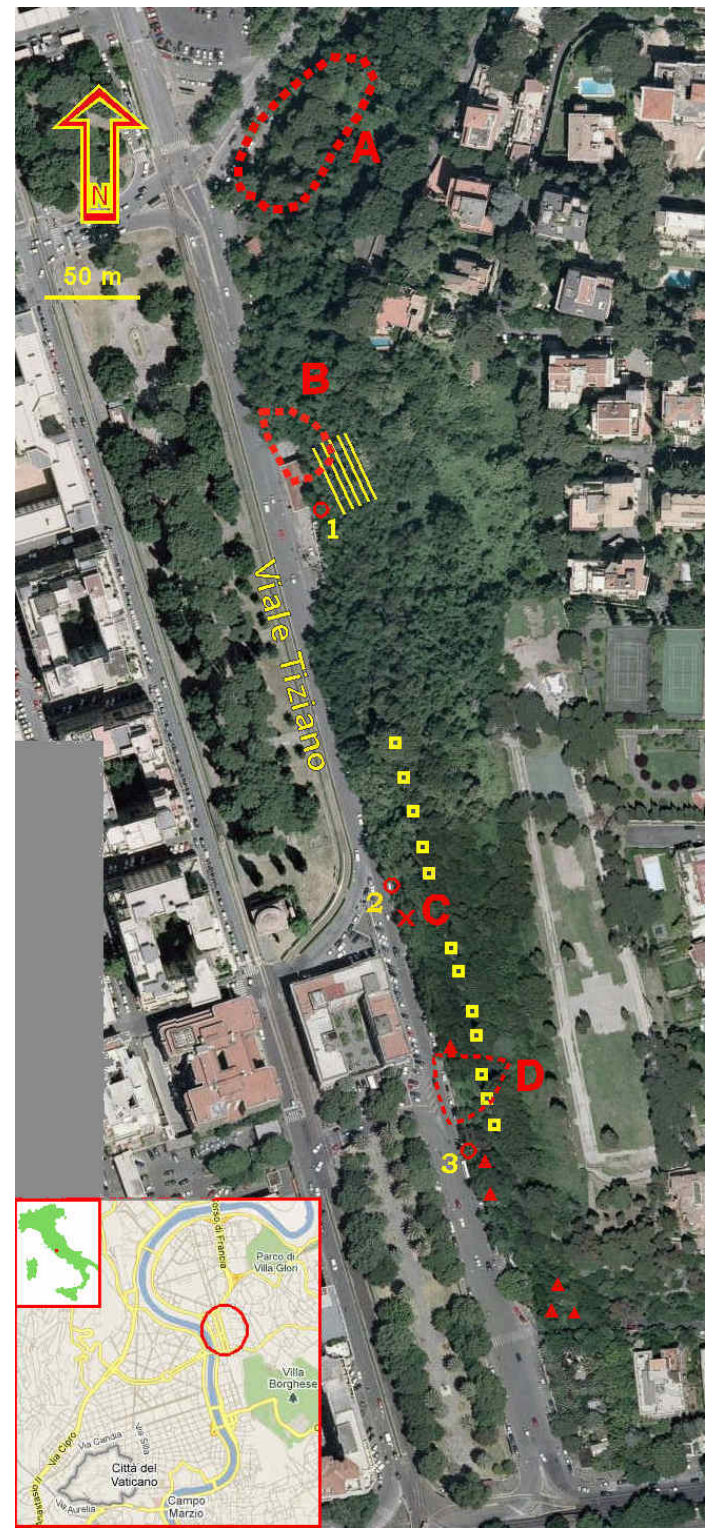

Fig. 3. The western slope of Monti Parioli hill (aerial photograph from Google Maps) and its position inside Roma city area. Letters show the position of previous landslide events (A, B, C) and of study event (D); parallel yellow lines show the portion of the slope remodelled into tiers after 1972 event; small yellow squares indicate the entrance of the upper cavity system; red triangles indicate rock blocks found at the foot of the slope; red circles (numbered in yellow with 1,2 and 3) indicate the accesses to the lower cavity system (WWII air-raid shelter).

(De Angelis D'Ossat, 1932), a cut made between 1926 and 1938 to build the last stretch of the Viale Tiziano, the excavation and remodelling of two cavity systems, cuts in 1961 and 1969 to make way for buildings and the expansion of a gas station (Colosimo, 1974), and remodelling of a portion of the slope into tiers in 1977 to accommodate a previous rock-fall (Amanti et al., 2008). 
Table 1. Overview on past landslide events.

\begin{tabular}{|c|c|c|c|c|}
\hline Year & Type of event & $\begin{array}{l}\text { Volume/length of land- } \\
\text { slide }\end{array}$ & Source/reference & Position in Fig. 3 \\
\hline Roman age & Rock-falls & $? ? ?$ & $\begin{array}{l}\text { Archeological report on } \\
\text { ancient Via Flaminia } \\
\text { layout }\end{array}$ & \\
\hline Before 1932 & $\begin{array}{l}\text { Author reports many events described in previ- } \\
\text { ous papers, mainly rock-falls and slidings }\end{array}$ & ??? Hundreds of $\mathrm{m}^{3}$ & $\begin{array}{l}\text { De Angelis } \\
\text { D’Ossat (1932) }\end{array}$ & \\
\hline 1963 & A rock-fall destroyed some parked cars & $\begin{array}{l}\text { Few cubic meters/few } \\
\text { meters }\end{array}$ & Colosimo (1974) & Site C \\
\hline March 1972 & $\begin{array}{l}\text { Two close rock-falls, occurred within a month } \\
\text { of each other, seriously damaged a gas station. }\end{array}$ & $40-300 \mathrm{~m}^{3} / 25 \mathrm{~m}$ & Colosimo (1974) & Site B \\
\hline $1983-1985(?)$ & $\begin{array}{l}\text { A sliding (?) caused the closure of a bending } \\
\text { road going uphill in the northern part of the } \\
\text { slope. }\end{array}$ & $\begin{array}{l}\text { Thousands of } \mathrm{m}^{3} / \text { about } \\
100 \mathrm{~m}\end{array}$ & Amanti et al. (2008) & Site A \\
\hline 2000-2008 & $\begin{array}{l}\text { Continuous small rock-falls along the whole } \\
\text { slope. }\end{array}$ & Up to few cubic meters & Amanti et al. (2008) & Red triangles \\
\hline 13 November 2007 & The studied rock-fall, object of present paper. & $450-600 \mathrm{~m}^{3} / 20 \mathrm{~m}$ & Direct survey & Site D \\
\hline $\begin{array}{l}\text { November } 2008- \\
\text { January } 2009\end{array}$ & $\begin{array}{l}\text { A shallow soil slip occurred twice on the north- } \\
\text { ern steep slope of the hill in a very busy street, } \\
\text { causing alarm and a long lasting road closure. }\end{array}$ & Few cubic meters & Direct survey & Out of the map \\
\hline December 2008 & $\begin{array}{l}\text { Many small rock-falls on the southern slope of } \\
\text { the hill. No damage. }\end{array}$ & Less then $1 \mathrm{~m}^{3}$ & Direct survey & Out of the map \\
\hline
\end{tabular}

Authors have reported the landslide susceptibility of the hill since the early studies of the northern area of Rome. De Angelis D'Ossat (1932) listed a number of events that were reported in previous papers. In March 1972, a collapse similar to the one in this study occurred approximately $300 \mathrm{~m}$ further north (Fig. 3, site B) and caused pitch and equipment damage at a gas station. A second rock-fall in the same area occurred approximately one month later. The total estimated volume of collapsed material was between $40 \mathrm{~m}^{3}$ and $300 \mathrm{~m}^{3}$. That portion of the slope was stabilised (Colosimo, 1974; Amanti et al., 2008, 2009) in 1977. Frequent collapses were limited to small blocks (up to a few $\mathrm{m}^{3}$ ) that have sometimes damaged property and injured people. A sudden collapse of travertine blocks in 1963 destroyed a car parked in the street (Fig. 3, site C). In 2008 and 2009, small boulders fell on a now-closed bike path and on the small road that runs along the south side of the hill.

At the northern limit of the slope (Fig. 3, site A), the "Salita dei Parioli" road, which provided access to the top of the hill from the west, was closed in the mid-1980s due to poorly defined landslide events at the second and third bend (Amanti et al., 2008).

\section{Surveys}

The locations of direct and indirect investigations conducted through a structured campaign are shown in Fig. 4.

Six boreholes were drilled, including four continuous cores and two destruction cores, to a depth between $30 \mathrm{~m}$ and $50 \mathrm{~m}$ below ground level, corresponding to the hilltop.
Three boreholes (BH1, SC2 and SC3) were equipped with open tube piezometers. Two boreholes (SD1 and SD2) were used to perform the cross-hole seismic tests (Table 2).

Undisturbed samples were collected during the drilling, and standard penetration tests (SPTs) were performed. Pressuremeter and permeability tests were completed using Menard and Lefranc devices.

Undisturbed samples were used to perform laboratory tests aimed at characterising the index properties, shear strength and deformability and compressibility parameters of the soils.

Laboratory analyses were performed on rock samples taken directly from the slope wall or foot using a core drill with a diamond blade. Simple compression, triaxial and indirect tensile tests such as the "Brazilian" test were performed on these samples.

A seismic survey and a geoelectric survey campaign were performed. Two seismic cross-hole sections and four linear surface seismic refraction surveys (L) were conducted. Three surveys (L1, L2 and L3 in Fig. 4) were performed along the fall line of the study slope. The analysis of seismic signal mitigation was conducted in addition to exploring the slope using $P$ wave velocity $(\mathrm{Vp})$ tomographic analysis. The fourth seismic line survey (L4) was performed on the top of the hill parallel to its outer edge and was the only measure of the Vp parameter.

Two electrical tomography surveys were performed on the top of the relief. The first survey (ELE2) near the edge of the slope coincides with the seismic line survey L4. The second electrical tomography survey (ELE1) extends parallel to the 
Table 2. Details of direct investigations.

\begin{tabular}{|c|c|c|c|c|c|c|c|c|c|c|c|}
\hline \multirow{2}{*}{$\begin{array}{l}\text { Borehole } \\
\text { identifier } \\
\text { SC1 }\end{array}$} & \multirow{2}{*}{$\begin{array}{l}\text { method } \\
\text { Continuous core }\end{array}$} & \multirow{2}{*}{$\begin{array}{r}\text { depth } \\
50.0\end{array}$} & \multicolumn{4}{|c|}{$\begin{array}{l}\text { Depth and results } \\
\text { of SPTs } \\
\text { (m) N1 N2 N3 }\end{array}$} & \multicolumn{2}{|c|}{$\begin{array}{l}\text { Depth and results of } \\
\text { Lefranc tests } \\
\text { (m) } \mathrm{K}\left(\mathrm{m} \mathrm{s}^{-1}\right)\end{array}$} & \multicolumn{2}{|c|}{$\begin{array}{l}\text { Depth and results of } \\
\text { of Menard tests } \\
\text { (m) E (kPa) }\end{array}$} & \multirow{2}{*}{$\begin{array}{l}\text { Borehole } \\
\text { equipment }\end{array}$} \\
\hline & & & 4.00 & 10 & 11 & 12 & 16.35 & $4.94 \times 10^{-4}$ & 12.50 & 110851 & \\
\hline & & & 15.00 & 15 & 23 & 26 & 38.05 & $3.96 \times 10^{-5}$ & 19.00 & 69166 & \\
\hline & & & 21.50 & 28 & 33 & 36 & & & 32.00 & 83344 & \\
\hline & & & 27.55 & 30 & $\mathrm{R}$ & & & & 41.80 & 101500 & \\
\hline & & & 35.00 & 19 & 17 & 28 & & & & & \\
\hline SC1dn1 & Destruction core & 50.0 & & & & & & & & & cross hole \\
\hline $\mathrm{SC} 1 \mathrm{dn} 2$ & Destruction core & 50.0 & & & & & & & & & cross hole \\
\hline \multirow[t]{5}{*}{$\mathrm{SC} 2$} & Continuous core & 50.0 & 5.55 & 8 & 10 & 7 & 14.9 & $2.79 \times 10^{-5}$ & 7.00 & 120060 & open tube piezometer \\
\hline & & & 8.80 & 7 & 10 & 24 & 28.95 & $3.15 \times 10^{-5}$ & 13.20 & 160965 & \\
\hline & & & 15.10 & 15 & 23 & 46 & 35.45 & $6.16 \times 10^{-7}$ & 26.30 & 194324 & \\
\hline & & & 22.00 & 20 & 23 & 52 & & & 27.90 & 33482 & \\
\hline & & & 36.55 & 14 & 17 & 38 & & & & & \\
\hline \multirow[t]{5}{*}{ SC3 } & Continuous core & 50.0 & 10.50 & 18 & 19 & 39 & & & & & open tube piezometer \\
\hline & & & 14.00 & 8 & 14 & 32 & & & & & \\
\hline & & & 20.00 & 14 & 15 & 31 & & & & & \\
\hline & & & 24.50 & 12 & 17 & 37 & & & & & \\
\hline & & & 27.50 & 6 & 12 & 25 & & & & & \\
\hline BH1 & Continuous core & 30.0 & & & & & & & & & open tube piezometer \\
\hline
\end{tabular}

first, but is in a rearmost position with respect to the front of the slope.

\section{Geological model}

\subsection{Geomorphological structure}

The study area falls within the urban area of Rome and is part of the western slope of the Monti Parioli Hill that runs near the Tevere River.

The hill has a sub-horizontal plateau summit, occupied by the public garden of Villa Balestra, which is bounded on the west by a short slope with high relief energy and a steepness close to $90^{\circ}$. The plateau culminates at an altitude of approximately $60 \mathrm{~m}$ a.s.1., whereas Viale Tiziano lies at approximately $18 \mathrm{~m}$ a.s.l. (Fig. 4).

Slopes generally show concave-convex profiles with a subvertical zone located between $30 \mathrm{~m}$ and $40 \mathrm{~m}$ above sea level. The slopes are characterised by frequent morphological recesses and steps of erosional and/or lithological origin.

The following two systems of cavities can be found along the escarpment: a lower one at the same level of Viale Tiziano (approximately $18 \mathrm{~m}$ a.s.l.) and a higher one (approximately $30 \mathrm{~m}$ a.s.l.). Access to both systems is forbidden and entrances are closed by iron gates.

The lower system was created as an air-raid shelter during World War II, was later used as a home and/or storage space, and is currently unused. It consists of three $40 \mathrm{~m}$ long access corridors, roughly perpendicular to the slope (entrances, numbered 1 to 3, are shown in Fig. 3), which lead to a $300 \mathrm{~m}$-long tunnel (approximately $6 \mathrm{~m}$ wide and 2-3 m high) parallel to Viale Tiziano. The inner walls have a masonry covering, and only one small vault collapse is visible. There is no perennial water flow, although there are obvious signs of calcareous deposits and water percolation, especially in the northern portion of the tunnel.

The upper system is composed of many artificial caves that do not communicate with each other. These caves extend into the slope for several meters and are located at altitudes between $30 \mathrm{~m}$ and $34 \mathrm{~m}$ a.s.l.. These caves, whose surfaces range from $4 \mathrm{~m}^{2}$ to more than $30 \mathrm{~m}^{2}$, have been excavated in the sandy silt formation, and the more resistant travertine banks act as a ceiling.

At the foot of the slope, there is a narrow detritic belt of moderate steepness that was generated as result of gravitational processes and is limited by a retaining wall, which sustains an artificial embankment seat of a bicycle path.

\subsection{Litostratigraphic structure}

The lithostratigraphic framework (Funiciello and Giordano, 2008) is characterised by the presence of volcaniclastic deposits on top of the relief, which are attributed to the formation of Tufi Stratificati Varicolori di Sacrofano (SKF) and Tufi Stratificati di La Storta (LTT) (Middle Pleistocene). They lie on the top of the Valle Giulia Formation (VGU), aged Middle Pleistocene, which overlaps the Monte Vaticano Formation (MVA) just below Viale Tiziano street level (Fig. 5).

The investigation campaign described earlier led to the establishment of a detailed lithostratigraphic model of the relief (Fig. 6). This lithostratigraphic relief model is needed as a detailed input for the 2-D and 3-D modelling. 


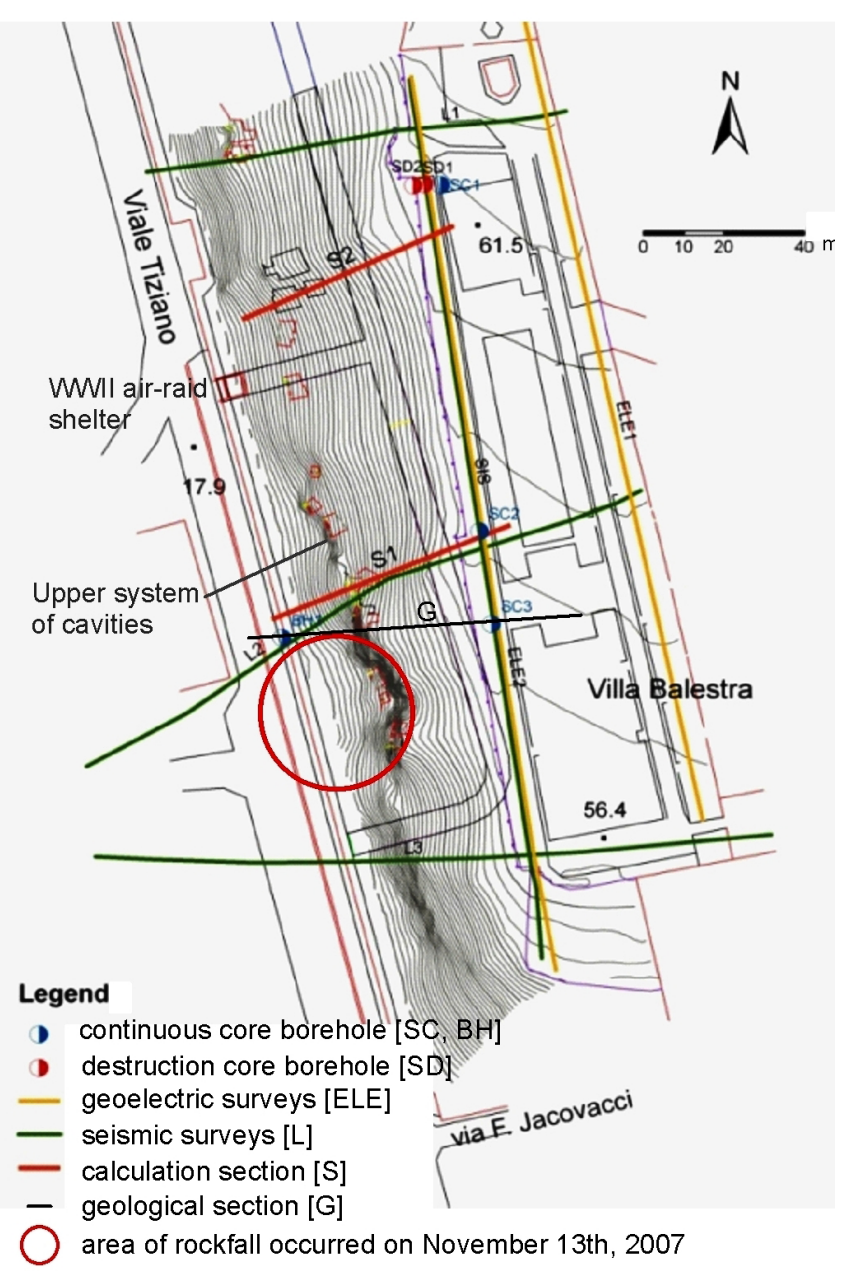

Fig. 4. Location of direct and indirect investigations.

There are several meters-thick landfills on the plateau summit consisting of reworked pyroclastic material, containing layers and pockets of sandy silt with calcareous concretions and limestone and laterite fragments. These deposits lie on incoherent pyroclastic materials consisting of a sequence of layers and banks of fine to medium ash with a particle size between that of sandy-clayey silt and sand with silt.

These pyroclastic materials, whose thickness is between $9 \mathrm{~m}$ (SC3 in Fig. 7) and $13 \mathrm{~m}$ (SC1), are characterised by compression wave velocity ( $\mathrm{Vp}$ ) values of approximately $0.5 \mathrm{~km} \mathrm{~s}^{-1}$ to $0.6 \mathrm{~km} \mathrm{~s}^{-1}$.

The terrains that belong to the Valle Giulia Formation, underlying pyroclastic materials, are mainly concretional sands and travertine. Sands are mainly composed of granular limestone by hydrothermal precipitation, but slag and volcanic mineral (altered leucite, pyroxene) pockets appear at various heights inside this formation. Some levels have lithoid travertine botryoidal concretions around traces of vegetation used as an accretion core.

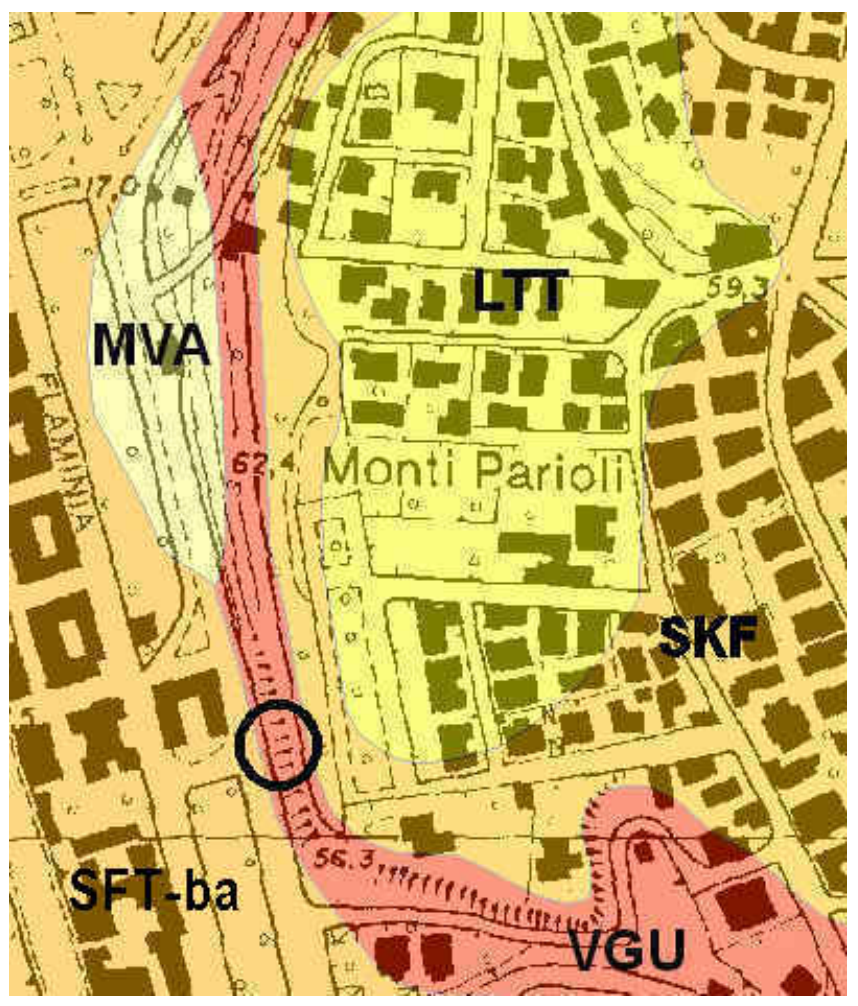

Fig. 5. Geological map of Monti Parioli area, from sheet 374 "Roma", 1: 50000 scale, Geological Map of Italy. The black circle indicates the location of the study event. Legend. SFT-ba: Tevere R. alluvial deposits (Holocene); LTT-SKF: Tufi Stratificati Varicolori di La Storta and Tufi Stratificati Varicolori di Sacrofano (Middle Pleistocene - Upper Pleistocene); VGU: Valle Giulia Formation (Middle Pleistocene); MVA: Monte Vaticano Formation (Lower Pliocene).

The stratification is poorly defined and the extent of cementation is variable. Some layers feature a lithoid or sometimes alabastroide appearance, whereas others are almost completely loose.

The results of the seismic surveys confirmed the structure of these deposits (Fig. 8), which are characterised by values of $\mathrm{Vp}$ between $0.5 \mathrm{~km} \mathrm{~s}^{-1}$ and $1.25 \mathrm{~km} \mathrm{~s}^{-1}$. These $\mathrm{Vp}$ values are slightly higher than those of the overlying pyroclastic materials.

The well-stratified light olive-brown silts and sands with widespread evidence of oxidation, present at the travertine bed, also belong to the Valle Giulia Formation. These sediments have a higher packing degree, as evidenced by higher $\mathrm{Vp}$ values (approximately $1.5 \mathrm{~km} \mathrm{~s}^{-1}$ ).

The basal portion of the Valle Giulia Formation consists of polygenic gravels made of calcareous and siliceous pebbles passing upward to quartz sand. The thickness of this lithological sub-unit is approximately $5 \mathrm{~m}$ and the structure of the deposit is low-angle cross-bedding. The gravel levels are generally well-sorted, but may have a coarse sandy 


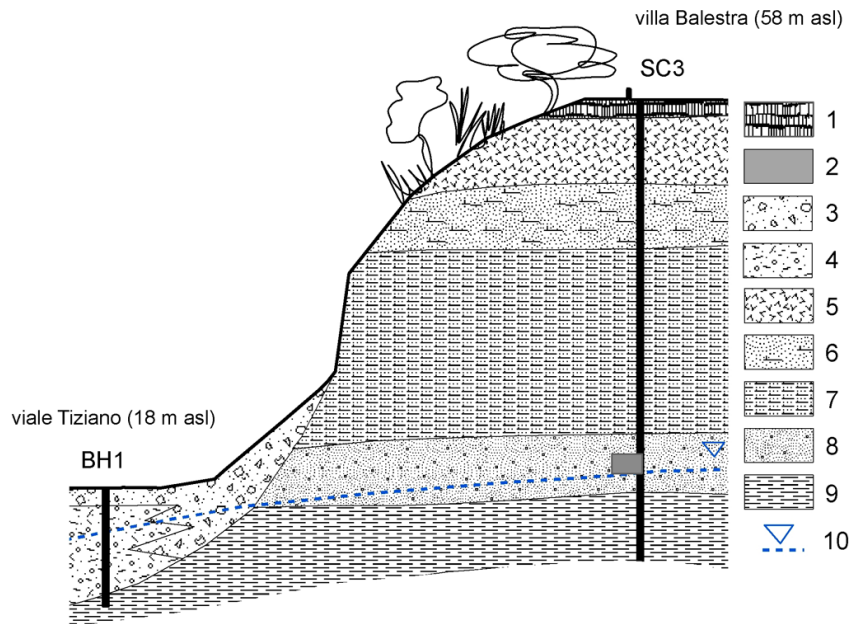

Fig. 6. Geological section. Legend: (1) human backfill and reworked pyroclastics; (2) WWII air-raid shelter; (3) slope detritus (Holocene); (4) Tevere R. alluvial deposits (Holocene); (5) loose pyroclastics (Middle Pleitocene-Upper Pleistocene); (6) calcareous sand (Middle Pleistocene); (7) silty to sandy calcareous beds and phytoclastic travertine (Middle Pleistocene); (8) fine to medium sand and gravel alluvial deposits (Middle Pleistocene); (9) overconsolidated silt and silty clay (Lower Pliocene); (10) water table.

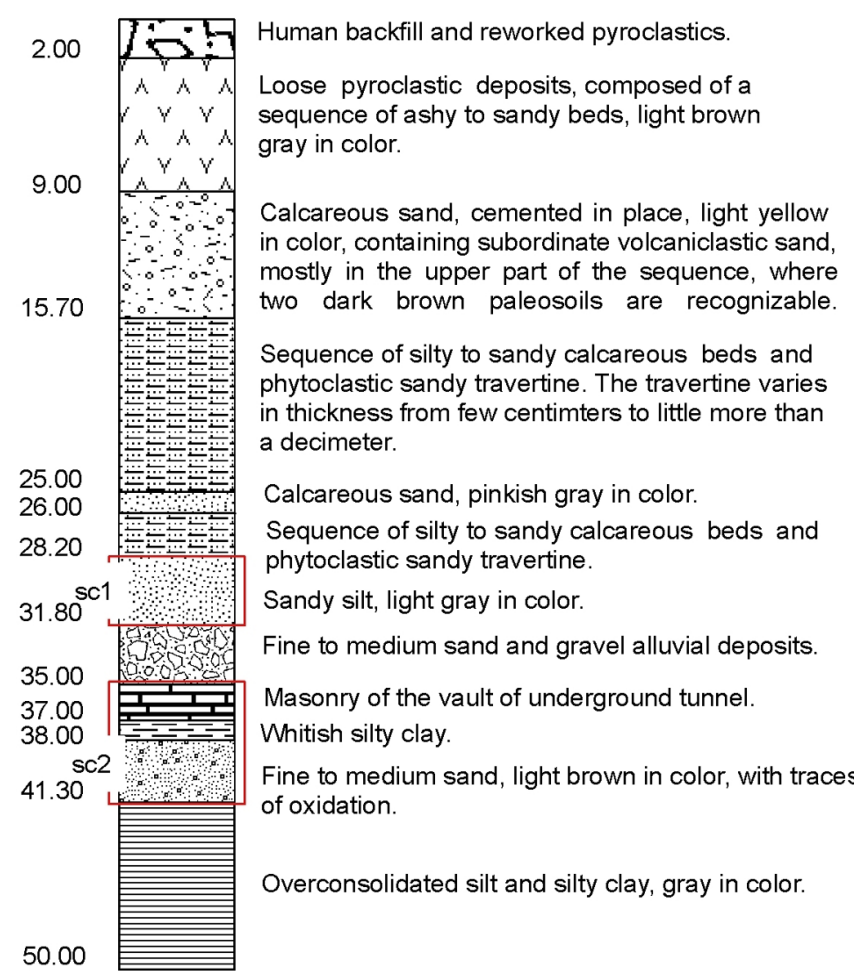

Fig. 7. Stratigraphic sequence of SC3 continuous core borehole. On the left, numbers indicate the depth from ground level. Legend: (sc1) terrains affected by the presence of the upper system of cavities; (sc2) terrains affected by the presence of the lower cavity system (WWII air-raid shelter).

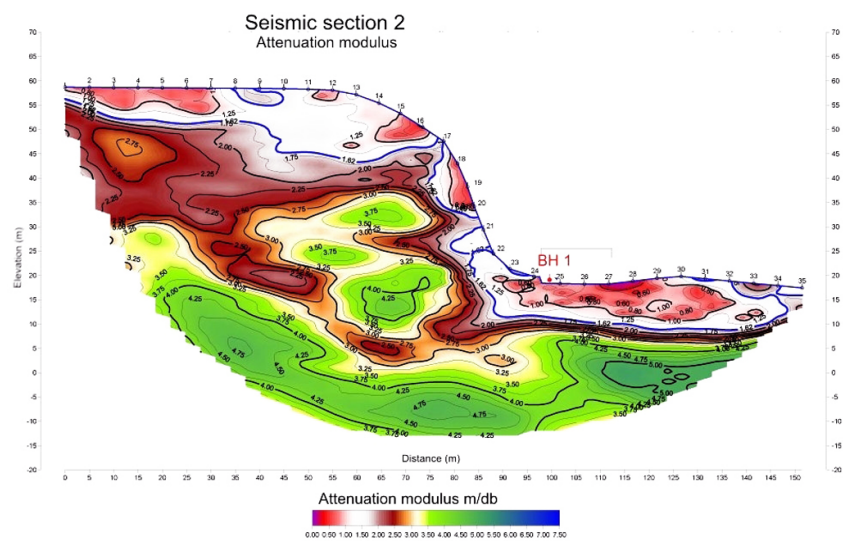

Fig. 8. Seismic survey, section 2. Compression wave velocity (Vp). On the top of the section, $\mathrm{Vp}$ values of $0.5-0.6 \mathrm{~km} \mathrm{~s}^{-1}$ may be associated with reworked and loose pyroclastic deposits (up to 15$20 \mathrm{~m}$ from the surface). Then a belt, slightly less degraded (Vp values between 0.5 and $1.25 \mathrm{~km} \mathrm{~s}^{-1}$ ), corresponding to the calcareous sands and sandy travertine. Getting deeper, $\mathrm{Vp}$ values are close to $1.5 \mathrm{~km} \mathrm{~s}^{-1}$, which couple with the presence of gravel layers with a higher cementation degree.

matrix. The deposit has a low degree of cementation and a high degree of packing.

The sands and gravels form the lower portion of the slope and were crossed by drillings at altitudes between $23 \mathrm{~m}$ and $17 \mathrm{~m}$ a.s.l. Gravels can be seen inside the lower tunnel network, but they are largely covered by the debris accumulation at the foot of the escarpment on the outer wall.

At an absolute altitude of approximately $17 \mathrm{~m}$ a.s.l., the Valle Giulia Formation sits on silt and clay belonging to the Monte Vaticano Formation (Pliocene), but the transition occurs at a level of several meters below (drilling BH1). The Monte Vaticano Formation is made of silt and laminated grey and blue-grey marly clay from consolidated to very consolidated, alternating with massive grey to yellow-coloured quartz-mica, fine-grained sands, consisting of medium to thin layers. The clay layers have a characteristic conchoidal fracture. Sandy levels appear to be loosely or slightly cemented.

The outcrops along the slope on Viale Tiziano show a widespread crack pattern consisting of gaping joints that develop parallel to the slope. The joints are sometimes tens of meters long; their opening ranges from few $\mathrm{cm}$ to $15 \mathrm{~cm}$. These fractures have an origin linked to rock mass detensioning in response to the natural slope retreating, and they play a key role in slope deterioration, favouring development of tree roots and infiltration of rainwater.

In agreement with these field observations, seismic surveys have shown that there are significant variations in the mechanic characteristics of the outcropping rocks, especially the shallow portion of the slope under investigation.

In the upper part of the slope, up to $10 \mathrm{~m}$ to $15 \mathrm{~m}$ inside it, the degradation of the sandy-travertine formation is 


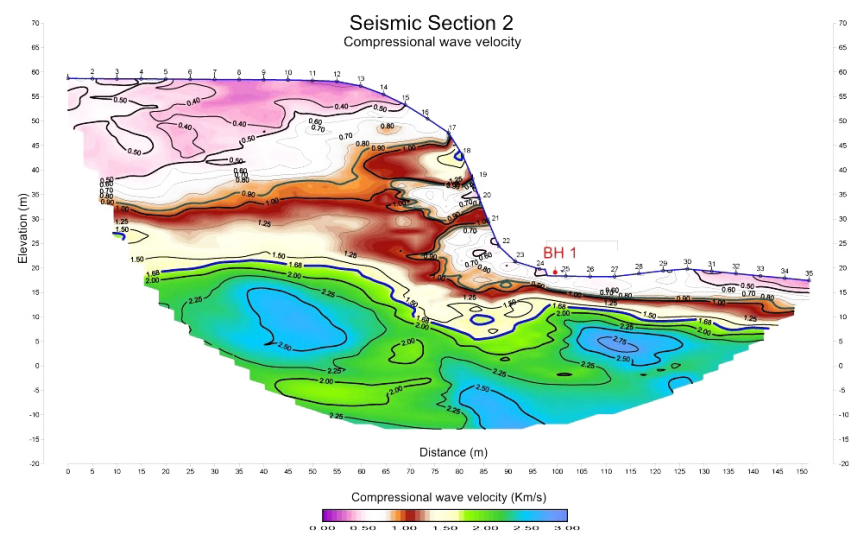

Fig. 9. Seismic survey, section 2 attenuation coefficient. The analysis of this parameter defines the degradation and fracturing of the rock mass. We can notice detensioned material areas towards the top edge of the escarpment (red colour). At the foot of the slope (geophones 21-24), an area with poor mechanical properties underlays a sector with very poor mechanical properties (geophones 18-20).

highlighted by the local decrease of Vp. Spots where Vp values are less then $0.6-0.7 \mathrm{~km} \mathrm{~s}^{-1}$ are visible (Fig. 8).

An analysis of the sections obtained using the attenuation module (a parameter generally very sensitive to the detection of degraded and fractured rock) are expressed as the reciprocal of the attenuation coefficient $\alpha$ :

$\alpha=\frac{\delta_{(f)}}{X_{2}-X_{1}}$

where $\delta_{(f)}=20 \log \left(A_{0} / A_{1}\right)$, and $A_{1}(X 2, f)=$ amplitude of the distance $X 2$ at frequency $f ; A_{0}(X 1, f)=$ amplitude of the distance $X 1$ at the frequency $f$ highlights the existence of a real detensioning of the material toward the top of the slope and toward the base of the escarpment (Fig. 9). This detensioning may be due to the degradation of the "tender" rock wall and to the presence of the underground cavities.

\subsection{Groundwater flow}

Rainwater infiltration feeds a small waterbed where the aquifer is the sandy gravel of the lower portion of the Valle Giulia Formation, lying on the clay of Monte Vaticano Formation.

The absolute altitude of the water table, measured in the drillings, was $20.80 \mathrm{~m}$ in the area of Parioli Hill. It decreased in the direction of Tevere River until reaching $11.9 \mathrm{~m}$ a.s.1. (Fig. 7). This level is in agreement with the published piezometric design (Ventriglia, 1971, 2002).

The water table stands at a lower level than the upper cave network, but it probably reaches the air-raid shelters level (lower cave system).

Measurements made during a hydrological year show a fluctuation of no more than $0.5 \mathrm{~m}$ in the water table level.

\section{Reconstruction of the engineering geological model}

To allow correct numerical modelling of the slope and to conduct the stability tests, the geological model has been simplified by combining the present lithologies in classes with similar mechanical characteristics.

Geotechnical characterisation of the travertine was performed at the ISPRA Soil and Rock Mechanics Laboratory. Soils and other terrains were tested both in ISPRA and in the Geostudi Laboratory of Pomezia (RM).

The mechanical characterisation was performed through laboratory tests on undisturbed samples and direct investigation such as SPTs and pressuremeter tests.

Geophysical surveys have been mainly used to define the geometry of the rock mass.

The final geotechnical stratigraphy was derived from direct drilling data and geophysical surveys. A cross-hole survey made it possible to identify five lithologies with similar elastic properties (Table 3). Further simplification was made by merging the upper travertine sands with the travertine $s$. The mechanical properties of materials are summarised in Table 4.

The issue that most affects the stability evaluation is the enormous variability of the parameters that characterise the strength of travertine and range from those related to a semicoherent terrain to a hard rock.

In Table 5 mechanical characteristics of the travertine in the area of collapse are shown.

\section{Stability check}

The first step was to conduct a back-analysis of the rock-fall event that occurred in November 2007.

It was possible to reconstruct the stability conditions of the slope at the time of collapse using the previously defined geological-technical model and all the parameters obtained from the field and laboratory tests.

The model was developed using a computational tool called two-dimensional Fast Lagrangian Analysis of Continua (FLAC). This tool is a two-dimensional explicit finite difference program for engineering mechanics computations (Cundall, 2005).

The algorithm directly examines the problem of determining the stress and strain fields in a domain whose characteristics are defined by the laws of elasticity and plasticity and within a boundary where certain conditions are imposed. The resistance values used in the simulation are shown in Table 3. The Mohr-Coulomb law was used.

Two geotechnical sections were then chosen to perform the stability analysis (see location in Fig. 4). The slope stability was initially tested without the presence of the caves and then the test was repeated with caves included in the model.

An algorithm called "strength reduction technique" was used to evaluate the safety factor with a stress-strain model. 
Table 3. Elastic properties defined by cross hole.

\begin{tabular}{|c|c|c|c|c|c|c|c|}
\hline Lithology & $\begin{array}{r}\text { Depth b.g.l. } \\
(\mathrm{m})\end{array}$ & $\begin{array}{r}\text { compressional-wave } \\
\text { velocity } \\
\mathrm{Vp}\left(\mathrm{km} \mathrm{s}^{-1}\right)\end{array}$ & $\begin{array}{r}\text { shear-wave } \\
\text { velocity } \\
\text { Vs }\left(\mathrm{km} \mathrm{s}^{-1}\right)\end{array}$ & $\begin{array}{l}\text { Poisson's } \\
\text { Ratio }\end{array}$ & $\begin{array}{r}\text { Elastic Young's } \\
\text { modulus } \\
\mathrm{E}(\mathrm{MPa})\end{array}$ & $\begin{array}{r}\text { Elastic shear } \\
\text { modulus } \\
\mathrm{G}(\mathrm{MPa})\end{array}$ & $\begin{array}{r}\text { Elastic bulk } \\
\text { modulus } \\
\mathrm{K}(\mathrm{MPa})\end{array}$ \\
\hline Pyroclastic materials & $0.0-13.0$ & 0.44 & 0.18 & 0.4 & 150 & 54 & 256 \\
\hline Travertine sand & $13.0-33.0$ & 0.61 & 0.23 & 0.41 & 258 & 91 & 533 \\
\hline Travertine medium to fine sand & $33.0-38.8$ & 0.99 & 0.22 & 0.38 & 254 & 85 & 2003 \\
\hline Sands and gravels & $38.8-44.5$ & 0.24 & 0.24 & 0.39 & 357 & 120 & 5486 \\
\hline Silt and clay & $44.5-50.0$ & 0.43 & 0.43 & 0.45 & 1212 & 409 & 11576 \\
\hline
\end{tabular}

Table 4. Physical and mechanical properties of materials.

\begin{tabular}{llrrrrr}
\hline Lithology & $\begin{array}{l}\text { Depth } \\
\text { b.g.l. } \\
\mathrm{m}\end{array}$ & $\begin{array}{r}\text { unit weight } \\
\mathrm{kN} \mathrm{m}^{-3}\end{array}$ & $\begin{array}{r}\text { Cohesion } \\
\mathrm{kPa}\end{array}$ & $\begin{array}{r}\text { Share resistance } \\
\text { angle } \phi \\
\left({ }^{\circ}\right)\end{array}$ & $\begin{array}{r}\text { Modulus of } \\
\text { elasticity E } \\
\text { GPa }\end{array}$ & $\begin{array}{r}\text { Poisson's Ratio } \\
v \\
-\end{array}$ \\
\hline Pyroclastics & $0.0-13.0$ & 16.5 & 20 & 26 & 33 & 0.4 \\
Travertine and travertinous sand & $13.0-38.8$ & 17.3 & $20-280$ & 44 & 1100 & 51 \\
Sands and gravels & $38.8-44.5$ & 18.0 & 5 & 32 & 42 & 0.38 \\
Silt and clay & $44.5-50.0$ & 20.4 & 30 & 28 & 0.45 \\
\hline
\end{tabular}

The algorithm gradually reduces the shear strength of the slope material until it reaches the steady-limit state, according to Dawson et al. (1999).

The safety factor obtained by starting from the geotechnical characterisation was equal to 1.5 ; therefore, the slope in absence of the cavity is stable.

The plastic state indicators that define whether the area is under elastic, plastic, at yield in shear or tension show that the most critical zone is approximately $30 \mathrm{~m}$ a.s.l. and is close to the cave position (Fig. 10).

The stability conditions significantly deteriorate after introducing the presence of the collapsed cavity into the model. Resistance values defined above are not sufficient to ensure stability. Where pre-collapse movements on top of the cave are highlighted (Fig. 11), it is possible to see that the triggering of the collapse is given by the presence of the cavity itself.

The 2-D analysis proposed here is conservative, because it cannot account for any vault effects in the direction perpendicular to the section.

Cohesion is the crucial parameter affecting stability, because of its wide range of values and because failure mechanisms in small cavities are characterised by low stress values for which cohesion is the strength component that most strongly affects stability. On the contrary, shear strength angle has a rather limited variability.

To account for the extreme variability of the cohesion characteristics of travertine, an option of the software that changes randomly the cohesion values, starting from a normal distribution characterized by a mean and standard deviation, was used in the model.

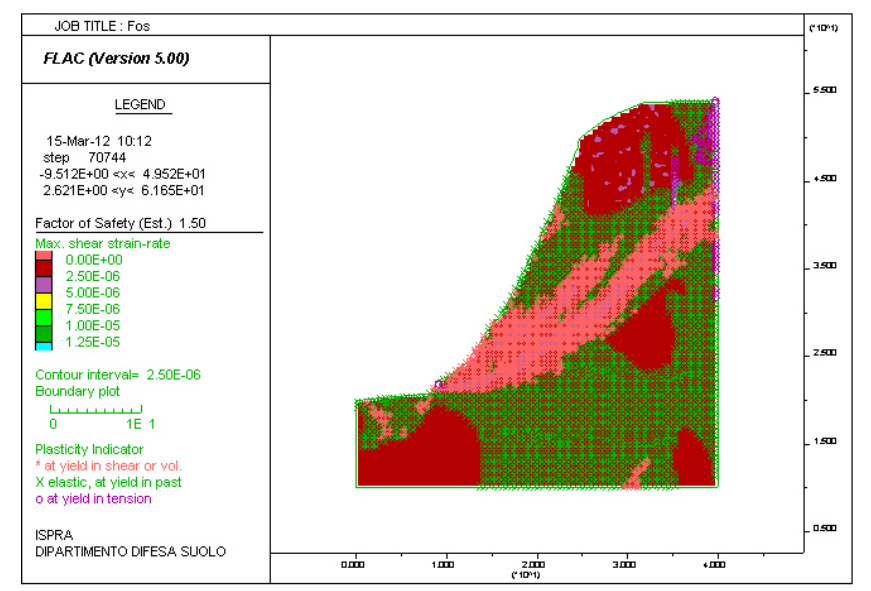

Fig. 10. Section 1. Safety factor and plasticity indicator. In the summit area of the slope, the shear strain rate distribution does not show a well-defined plane of shear failure, but a general state of collapse. The plastic indicators show a state of spread yield at the altitude of $30 \mathrm{~m}$ a.s.1., corresponding to the position of the caves. The simulation is not really significant in the vicinity of the right peripheral zone, due to an "edge effect". The strength values represent the shear strength of the slope material before the application of the reduction technique.

The present approach was adopted as a pure calculation assumption even if, formally, the distribution of cohesion values is not Gaussian, as shown by the Shapiro-Wilk tests (Shapiro and Wilks, 1965).

Testing the second section seems to be more complex, because many caves with a very articulated layout are present. 
Table 5. Physical and mechanical characteristics of travertine from the area of collapse.

\begin{tabular}{|c|c|c|c|c|c|}
\hline Sample & $\begin{array}{l}\text { Unit Weight } \\
\qquad \mathrm{kN} \mathrm{m}^{-3}\end{array}$ & $\begin{array}{r}\text { Uniaxial } \\
\text { compression } \\
(\mathrm{MPa})\end{array}$ & $\begin{array}{r}\text { Elastic } \\
\text { Modulus } \\
(\mathrm{GPa})\end{array}$ & $\begin{array}{r}\text { Tensile } \\
\text { strenght } \\
\mathrm{MPa}\end{array}$ & $\begin{array}{r}\text { Cohesion } \\
(\mathrm{KPa})\end{array}$ \\
\hline 116 & & & & 0.21 & \\
\hline 117 & & & & 0.19 & \\
\hline 121 & & & & 0.06 & \\
\hline 122 & & & & 1.19 & \\
\hline 123 & & & & 0.17 & \\
\hline 124 & & & & 0.55 & \\
\hline 125 & & & & 1.56 & \\
\hline 126 & & & & 0.37 & \\
\hline 127 & 15.50 & 1.01 & 2.03 & & \\
\hline 128 & 14.40 & & & & \\
\hline 129 & 16.20 & 2.05 & 0.03 & & \\
\hline 130 & 17.20 & 4.05 & 0.06 & & 58.00 \\
\hline 131 & 13.05 & 0.09 & 0.02 & & 17.00 \\
\hline 132 & 16.60 & 3.00 & 0.08 & & \\
\hline 133 & 13.90 & 2.04 & 0.04 & & \\
\hline 134 & 13.80 & 1.06 & 0.02 & 0.41 & 21.00 \\
\hline $134 / 2$ & 13.70 & 2.01 & 2.06 & 0.39 & 22.00 \\
\hline $134 / 3$ & 10.60 & 0.07 & 0.08 & 0.31 & \\
\hline $134 / 4$ & 13.90 & & & & \\
\hline 135 & 14.70 & 0.08 & 0.08 & & \\
\hline $135 / 2$ & 13.40 & 1.03 & 0.03 & & \\
\hline 136 & 16.20 & 5.00 & 0.06 & 0.06 & \\
\hline 137 & 13.06 & & & 1.53 & \\
\hline $137 / 2$ & 16.04 & & & & \\
\hline MEAN & 14.516 & 1.791 & 0.38 & 0.49 & 29.50 \\
\hline STANDARD DEVIATION & 1.700 & 1.582 & 0.78 & 0.53 & 19.12 \\
\hline
\end{tabular}

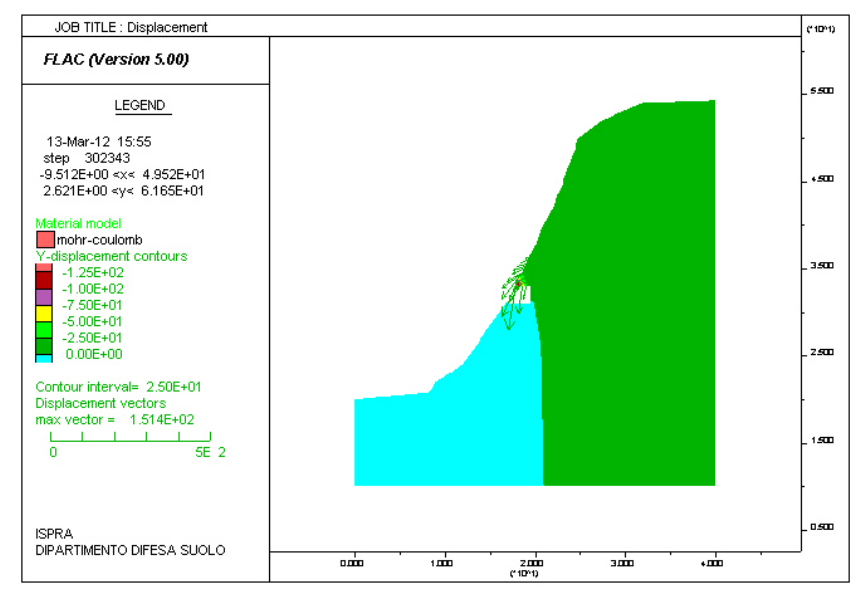

Fig. 11. Section 1. Displacement vectors in the pre-collapse movements. The simulation includes the presence of a cave in the section. The resulting collapse mechanism is definitely linked to the collapse of the vault of the cave. The simulation process stops for an excessive deformation that distorts the computing grid beyond the accepted limits.
Anyway, as well as in Sect. 1, the slope without cavities is stable.

Running the model is difficult after the insertion of the caves in the section, because of the limitations of 2-D diagrams. The resulting 2-D section along two caves and a corridor shows an extended hollow that is excessively burdensome and unrealistic for the stability test. The geological technical model for Sect. 2 is shown in Fig. 12. It is almost impossible to perform a valid two-dimensional test with this geometry.

So it was necessary to test the slope stability using a 3-D model. The chosen software was COMSOL Multiphysics (formerly FEMLAB). It is a finite element analysis and solver software package for various physics and engineering applications, especially for coupled or complex phenomena.

The travertine was modelled with a Drucker-Paeger constitutive equation in order to fit to the Mohr-Coulomb law.

To obtain this result, the approximation proposed by HaiSui (2006) for a three-dimensional yield surface was used starting from the Drucker-Prager (1952) criterion.

The failure criteria of the yield surface for material models depend on the two strength parameters, cohesion $c$ and 


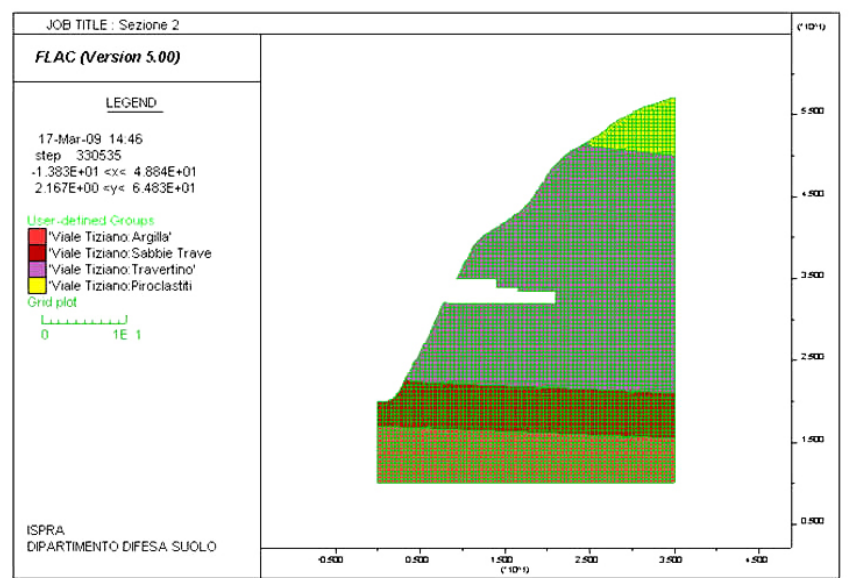

Fig. 12. Section 2. Geological technical model. It has been defined according both to geological field survey and to the results of all carried investigations. This conceptual model represents the stratigraphical conditions and the pore pressure regime, and takes into account the physical and mechanical characterisation of soils to define a numerical model capable of predictive analysis.

friction angle $\phi$, and on two stress quantities, the hydrostatic stress and the equivalent deviatoric stress.

The yield surface $\mathrm{F}$ for the Drucker-Prager material law is given by AAVV (2007):

$F=3 \alpha \sigma_{\mathrm{m}}+\sigma_{\mathrm{eqv}}-K$

where $\alpha=\frac{2 \sin \phi}{\sqrt{3}(3-\sin \varphi)}$ and $K=\frac{6 c \cos \phi}{\sqrt{3}(3-\sin \varphi)}$.

The hydrostatic stress (mean stress) is $\sigma_{\mathrm{m}}$ and $\sigma_{\text {eqv }}$ is the equivalent deviatoric stress.

The hydrostatic stress is defined using the normal stress components $\sigma_{i i}$ :

$\sigma_{\mathrm{m}}=\frac{\sigma_{i i}}{3}=\frac{\sigma_{x}+\sigma_{y}+\sigma_{z}}{3}$.

The equivalent deviatoric stress is defined using the deviatoric stress components:

$\sigma_{\text {eqv }}=\sqrt{\frac{1}{2} s_{i j} s_{i j}}=\sqrt{\frac{1}{2}\left(s_{x}^{2}+s_{y}^{2}+s_{z}^{2}\right)+s_{x y}^{2}+s_{y z}^{2}+s_{z x}^{2}}$

where the deviatoric stress components $s_{i j}$ are defined by

$$
\begin{aligned}
& s_{i j}=\sigma_{i j}-\frac{\delta_{i j} \sigma_{k k}}{3} . \\
& \text { or } s_{x}=\sigma_{x}-\sigma_{\mathrm{m}} \quad \sigma_{x y}=\tau_{x y} \\
& s_{x}=\sigma_{y}-\sigma_{\mathrm{m}} \quad \sigma_{y z}=\tau_{y z} \\
& s_{x}=\sigma_{z}-\sigma_{\mathrm{m}} \quad \sigma_{z x}=\tau_{z x} .
\end{aligned}
$$

The shape and characteristics of the slope were modelled using the moving meshes technique and the results are shown in Fig. 13. In this mode, the studied sub-domain is free to deform as determined by the boundary conditions.

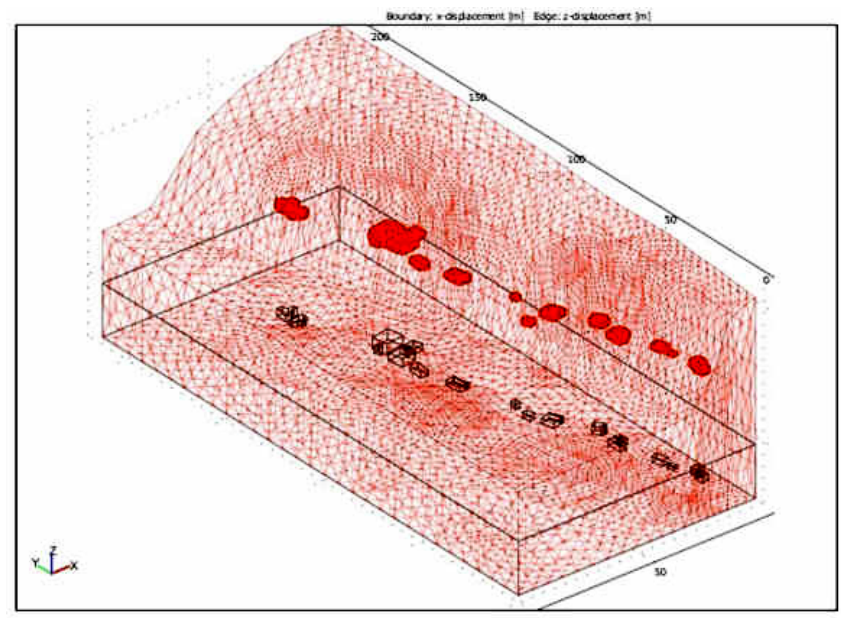

Fig. 13. Geometrical 3-D model. The $3-\mathrm{D}$ model is included in a box of $100 \times 50 \times 220 \mathrm{~m}$. Caves shapes have been drawn at the base of the slope, then moved at the right altitude through the methodology of moving meshes. Generic tetrahedral type elements were used; the degree of freedom for the system is equal to 15000 .

The portion of the slope tested using 3-D methodology had a length of $220 \mathrm{~m}$ and a depth of $100 \mathrm{~m}$. The slope was initially analysed without the presence of caves.

A parametric analysis was performed by decreasing the value of cohesion to all the volume occupied by travertine until the model became unstable.

The critical value of cohesion is approximately $22 \mathrm{kPa}$ (Fig. 14). This value is slightly lower than the one from 2-D analysis, but that is in agreement with the fact that the 2-D analysis is generally more conservative.

The final test was run to evaluate the overall stability of the slope, including the presence of caves in the threedimensional physical model.

The following parameters describe the conditions of the approaching collapse:

- the plastic deformation evolution tends to evolve even under a constant load and eventually leads the slope to collapse;

- the equivalent deviatoric stress, defines the failure criteria together with the geotechnical characteristics.

\section{Conclusions}

A very complete survey campaign was conducted to obtain the values of the parameters necessary to assess the slope stability.

The 2-D modelling was not sufficient to assess the stability of the complex slope where underground caves with articulated layouts were present. In a 2-D section it is difficult to correctly simulate the vault effect across the study sections. 

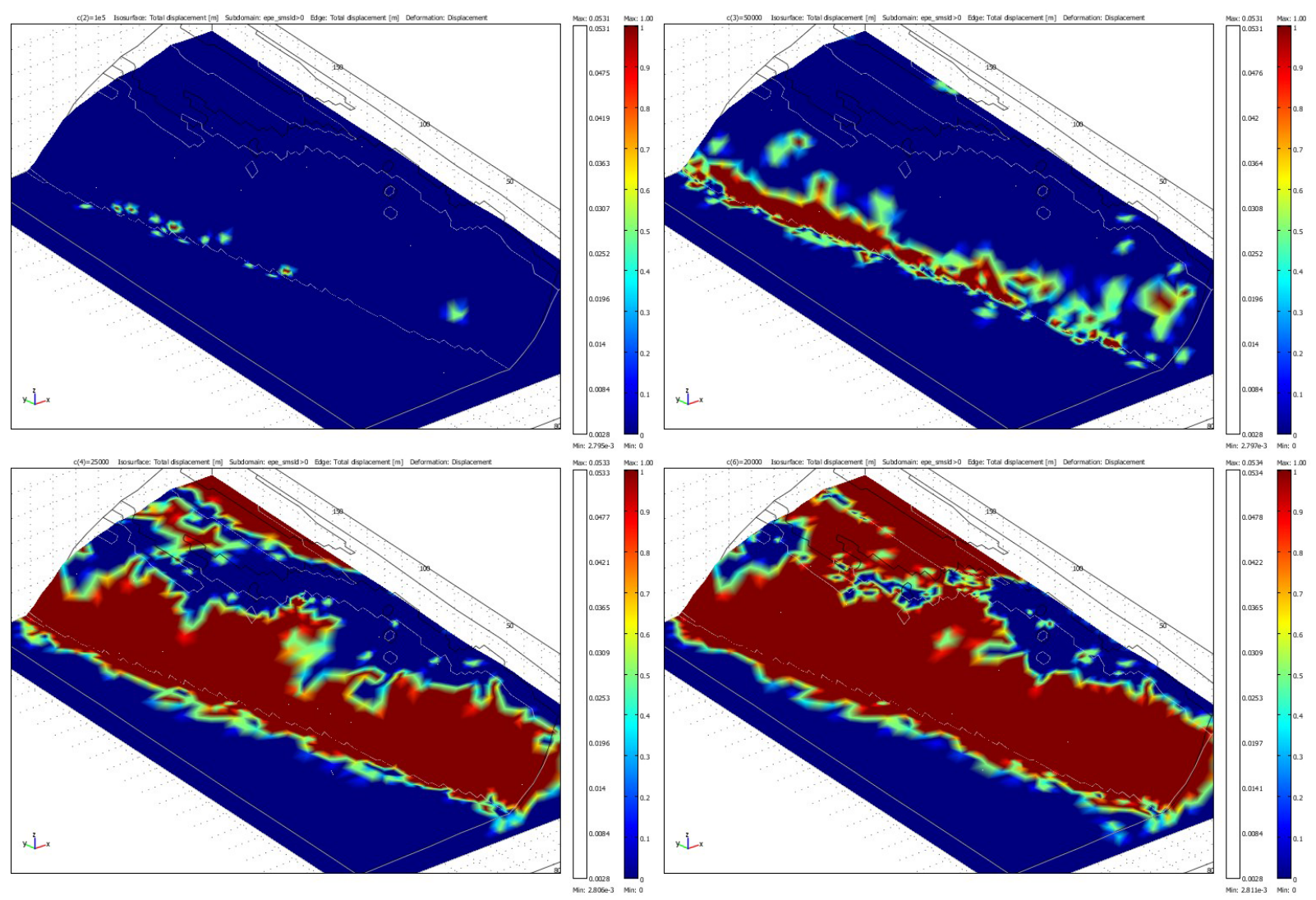

Fig. 14. 3-D Stability model. Parametric analysis on cohesion. The parametric analysis on cohesion emphasizes a progressive buckling starting from the foot of the slope area; it highlights the negative role on the stability carried out by the cavities. Using a finite element method, as well as shown in Fig. 11 using a finite difference method, it is not possible to evaluate the post-collapse behavior, because the computing system becomes unstable.

The 3-D modelling was used to test the study slope. The resistance parameter that most affects the stability is cohesion. The variation of cohesion values is inextricably linked to the genetic process of travertine and sand concretions whose vertical and horizontal heteropy are very conspicuous. Therefore, mechanical characterisation of these lithotypes is extremely difficult, although field and laboratory investigations have been particularly detailed.

Despite the use of 2-D stress-strain calculations, tests suffered from a lack of precision related to the intrinsic nature of the lithology.

Nevertheless, the 3-D model shows that the rock-fall may have been triggered in the absence of rainfall or external forces such as earthquakes or ground vibrations. The rockfall was presumably due to a type of rheological behaviour of the lithoid material.

The modelling emphasised the negative stability due to the existence of the underground caves.

Given the virtually instantaneous collapse, the studied rock-fall is linked to the collapse of the vault of a pre-existing cave that subsequently made the entire slope above it instable.
The presence of pre-existing sub-vertical fractures and the action of tree roots inside them may have facilitated the collapse.

Edited by: F. Luino

Reviewed by: two anonymous referees

\section{References}

AAVV: Comsol multiphysics Ver. 3.4 User's guide, 2007.

Amanti, M., Cesi, C., and Vitale, V.: Le frane nel territorio di Roma, in: La geologia di Roma dal centro storico alla periferia, edited by: Funiciello, R., Praturlon, A., and Giordano, G., Mem. Descr. Serv. Geol. d'It., LXXX, 83-117, 2008.

Amanti, M., Cesi, C., and Vitale, V.: Frane in area urbana: il caso di Roma, Rend. Online Soc. Geol. It, 6, 5-6, 2009.

Colosimo, P.: Il dissesto di Viale Tiziano in Roma: Studio di geologia ambientale applicato alla tecnologia dell' Architettura, Geologia Tecnica, 3, 129-142, 1974.

Cundall, P.: Flac Ver. 5.0 User's guide, Itasca Consulting group, Minneapolis USA, 2005. 
Dawson, E. M., Roth, W. H., and Drescher, A.: Slope Stability Analysis by Strenght Reduction, Geotecnique, 49, 835-840, 1999.

De Angelis D'Ossat, G.: La geologia e le catacombe romane/memoria quinta di Gioacchino de Angelis D'Ossat. Memorie della Pontificia Accademia delle Scienze, Nuovi Lincei, S.2, 16, 873-911, 1932.

Drucker, D. C. and Prager, W.: Soil Mechanics and plastic analysis for limit design, Q. Appl. Math., 10, 157-165, 1952.
Funiciello, R. and Giordano, G.: Geological Map of Italy (scale 1: 50,000), Sheet 374, S.EL.CA., Firenze, 2008.

Hai-Sui, Y.: Plasticity and Geotechnics, Springer, 79-80, 2006.

Shapiro, S. S. and Wilk, M. B.: An analysis of variance test for normality (complete samples), Biometrika, 52, 591-611, 1965.

Ventriglia, U.: La geologia della città di Roma, Amministrazione Provinciale di Roma, 417 pp., 1971.

Ventriglia, U.: Geologia del territorio del comune di Roma, Amministrazione Provinciale di Roma, 809 pp., 2002. 